Volume 9, No.5, September - October 2020

International Journal of Advanced Trends in Computer Science and Engineering Available Online at http://www.warse.org/IJATCSE/static/pdf/file/ijatcse113952020.pdf

https://doi.org/10.30534/ijatcse/2020/113952020

\title{
Outcome of Online Teaching-Learning over Traditional Education during Covid-19 Pandemic
}

\author{
Gautam Kumar $^{1}$, Gulbir Singh ${ }^{2}$, Vivek Bhatnagar ${ }^{3 *}$, Rajeev Gupta ${ }^{4}$, Sushil Kumar Upadhyay $^{5}$ \\ ${ }^{1}$ Assistant Professor, MMICT\&BM(MCA), M. M. (Deemed to be University), Mullana, Ambala, Haryana, India, \\ gautam.bopara@gmail.com. \\ ${ }^{2}$ Assistant Professor, MMICT\&BM(MCA), M. M. (Deemed to be University), Mullana, Ambala, Haryana, India, \\ gautam.bopara@gmail.com. \\ $3^{3 *}$ Associate Professor, MMICT\&BM(MCA), M. M. (Deemed to be University), Mullana, Ambala, Haryana, India, \\ vivek.bhatnagar@mmumullana.org(Corresponding Author) \\ ${ }^{4}$ Assistant Professor, Computer Sc. \& Engg., MMEC, M. M. (Deemed to be University), Mullana, Ambala, Haryana, \\ India, rajeev.gupta@mmumullana.org. \\ ${ }^{5}$ Assistant Professor, Department of BioTech, MMEC, M. M. (Deemed to be University), Mullana, Ambala, Haryana, \\ India, upadhyay.k.sushil@gmail.com
}

\begin{abstract}
The purpose of this study is to assess the impact, issues, and tools of online teaching-learning throughout the various higher educational bodies (colleges/Universities) across India. An online survey was conducted from $29^{\text {th }}$ June to $20^{\text {th }}$ July 2020. The questionnaire has closedended questions with multiple choice answer options for analysis using quantitative methods. During the investigation, it has been observed online teaching played a crucial role in education during the COVID-19 pandemic but lack of resources and proper training are the major issues during ICT based/Online teaching-learning. The problem in the selection of a perfect tool for teaching-learning electronically was the reason that could not make it impactful as compared to the conventional education system. This study will help government authorities, educational bodies to draft a training/advisory program for students and teachers to overcome the issues found in the study. It will help in making online education a more attractive and powerful medium for teachinglearning activities that ensure the development of young scholars, skill-set, employability.
\end{abstract}

Key words: COVID-19 Pandemic, ICT, Online education, Web-based education.

\section{INTRODUCTION}

The novel coronavirus disease (nCoV-19) was firstly reported in Wuhan, Hubei Province of China at the end of the year 2019. The World Health Organization [19,21] declared it as 'pandemic' on $11^{\text {th }}$ March 2020; due to the rapid spreading of coronavirus disease 2019 (COVID-19) [17]. A common goal was initiated to curb the spread of nCoV-19 by most of the governments globally through striking lockdown, maintaining social/physical distancing, avoiding face to face (conventional) teachinglearning, and restricting immigration [5]. Over the globe, around 600 million learners are affected due to the shutting down of educational bodies [6]. In a report by [16], it was stated that near about 320 million learners are affected in India. On 30th Jan 2020, in India (Kerla) the first patient was reported COVID-19 positive [18].
Currently, India has a speedy growth in COVID-19 cases. As of 6th September 2020, India has reported 862,320 active cases, 3,180,865 recovered cases, and 70,626 death cases [10]. The central government of India along with state governments have initiated several strategies like Janta curfew and lockdown to curb the spread of the disease [14]. From 25th March 2020 to 31st May 2020, India has observed four phases of nationwide lockdown. In India, the unlock process started from $1^{\text {st }}$ June 2020 and essential services are resuming in a wellplanned way. Currently, its unlock 4.0 from $1^{\text {st }}$ to $30^{\text {th }}$ September 2020.

During the COVID-19 outbreak, closure of academic ventures left unprecedented impacts on education (teaching-learning process) [1]. During the lockdown, Teachers are instructed to teach through online learning platforms like zoom, MSteams, YouTube, etc. stating that there is a need for adoption of new technologies to continue the teaching-learning process. Students are in the dilemma of accepting the new education system "elearning" [2]. The COVID-19 outbreak results in the digital revolution in the higher education system through online lectures, teleconferencing, digital open books, online examination, and interaction at virtual meeting platforms $[9,15,22]$. "Distance education has managed very well without any theory" it was remarked Over 39 years ago [12] The same can be said today about elearning and ICT (Information Communication Technology) based learning. In the last decades, online learning practice has achieved momentum and it will be the central tool for future education. WhatsApp also played an effective role in higher education as a platform for sharing information about learning [4]. The main issue in shifting to e-learning from conventional learning is a barrier to adoption, so, it is important to select an elearning process with the use of different technologies for education as well as for daily routine activities to improve the knowledge of learners [13, 23]. The online mode of the teaching-learning process is often discriminatory to poor and marginalized students [20]. During this lockdown period, the closing of academic ventures hampered the education system and the teaching-learning 
process. Understanding the teaching-learning process in this crisis period is imperative to design effective interventions for the smooth running of teaching and learning [11]. Online education became the panacea for teaching-learning in the time of the current crisis [3]. with these backdrops, the present study aims to identify the impacts of e-learning compared with conventional learning during this lockdown amidst the COVID-19 pandemic [7,8].

\section{DATA AND METHODS}

\subsection{Subjects}

The study was based on the 210 participants (156 students, 54 teachers) belonging to various institutions/ Universities across India (Table 1).

Table 1: The state wise number of participants during an online survey.

\begin{tabular}{|l|l|c|c|c|}
\hline $\begin{array}{c}\text { S. } \\
\text { No. }\end{array}$ & \multicolumn{1}{|c|}{ State } & $\begin{array}{c}\text { No. of } \\
\text { Teachers } \\
\mathbf{( 5 4 )}\end{array}$ & $\begin{array}{c}\text { No. of } \\
\text { Students } \\
\mathbf{( 1 5 6 )}\end{array}$ & $\begin{array}{c}\text { Total } \\
\text { Participants } \\
\mathbf{( 2 1 0 )}\end{array}$ \\
\hline $\mathbf{1}$ & Assam & 0 & 1 & 1 \\
\hline $\mathbf{2}$ & Bihar & 0 & 17 & 17 \\
\hline $\mathbf{3}$ & Delhi & 2 & 0 & 2 \\
\hline $\mathbf{4}$ & Gujrat & 1 & 1 & 2 \\
\hline $\mathbf{5}$ & Haryana & 24 & 110 & 134 \\
\hline $\mathbf{6}$ & $\begin{array}{l}\text { Himachal } \\
\text { Pradesh }\end{array}$ & 0 & 1 & 1 \\
\hline $\mathbf{7}$ & $\begin{array}{l}\text { Jammu } \\
\text { \&Kashmir }\end{array}$ & 1 & 1 & 2 \\
\hline $\mathbf{8}$ & Jharkhand & 0 & 2 & 2 \\
\hline $\mathbf{9}$ & $\begin{array}{l}\text { Madhya } \\
\text { Pradesh }\end{array}$ & 0 & 2 & 2 \\
\hline $\mathbf{1 0}$ & Maharashtra & 2 & 1 & 3 \\
\hline $\mathbf{1 1}$ & Orissa & 1 & 0 & 1 \\
\hline $\mathbf{1 2}$ & Punjab & 3 & 2 & 5 \\
\hline $\mathbf{1 3}$ & Rajasthan & 2 & 0 & 2 \\
\hline $\mathbf{1 4}$ & Tamil Nadu & 1 & 6 & 7 \\
\hline $\mathbf{1 5}$ & Telangana & 2 & 2 & 4 \\
\hline $\mathbf{1 6}$ & Uttar & 14 & 10 & 24 \\
\hline $\mathbf{1 7}$ & Pradesh & & & 1 \\
\hline & Uttarakhand & 1 & 0 & \\
\hline & & & & \\
\hline
\end{tabular}

\subsection{Data collection and procedure}

This is an online survey based on a questionnaire focussing on current issues in higher education after adopting the online teaching/ learning system. The esurvey was conducted using 'Google form' from $29^{\text {th }}$ June to $20^{\text {th }}$ July 2020 to collect the information. The questionnaire comprised eighteen questions dealing with various dimensions of constraining, merits, demerits, relevance, optimal application, and impact of conventional and online teaching/learning techniques (Table 2). A structural questionnaire link was sent to participants through e-mail and social media platforms. The participants were provided full consent and confidentiality of their personnel information before participating in the online survey.
Table2: The summary of questions in an online survey.

\begin{tabular}{|c|c|}
\hline S. No. & Question \\
\hline I. & $\begin{array}{l}\text { Face-to-face interaction during class time in } \\
\text { the traditional system increases the } \\
\text { confidence level of a student. }\end{array}$ \\
\hline II. & $\begin{array}{l}\text { Adopting ICT and e-learning allows us to } \\
\text { acquire new knowledge and enhance their } \\
\text { skill set. }\end{array}$ \\
\hline III. & $\begin{array}{l}\text { Everyone knows the power of digital media } \\
\text { and their usage in e-learning; but it reduces } \\
\text { practical exposure in real life especially in } \\
\text { the field of medical, civil, dental, } \\
\text { architecture, etc. }\end{array}$ \\
\hline IV. & $\begin{array}{l}\text { Lack of digital resources } \\
\text { (computer/PC/laptop) and their usage in } \\
\text { rural/interior areas of India while adopting } \\
\text { ICT and e-learning. }\end{array}$ \\
\hline V. & $\begin{array}{l}\text { The big challenges while adopting ICT- } \\
\text { based eLearning are data privacy and } \\
\text { security. }\end{array}$ \\
\hline VI. & $\begin{array}{l}\text { Learners can't see the real-world } \\
\text { implications of the e-learning course. }\end{array}$ \\
\hline VII. & $\begin{array}{l}\text { Which technical platform you are using for } \\
\text { online classes? }\end{array}$ \\
\hline VIII. & $\begin{array}{l}\text { How do you feel during online } \\
\text { teaching/learning as compared to classroom } \\
\text { teaching/learning? }\end{array}$ \\
\hline IX. & $\begin{array}{l}\text { Which problems have you faced during } \\
\text { online classes? }\end{array}$ \\
\hline X. & $\begin{array}{l}\text { What is the reaction of your family about } \\
\text { online classes? }\end{array}$ \\
\hline XI. & $\begin{array}{l}\text { Which online resources and portal best suit } \\
\text { your requirement for e-teaching? }\end{array}$ \\
\hline XII. & $\begin{array}{l}\text { Which is the best medium to disseminate } \\
\text { course contents and notes to the e-learner? }\end{array}$ \\
\hline XIII. & $\begin{array}{l}\text { Have you used ICT for the e-Learning } \\
\text { platform before the Covid- } 19 \text { pandemic? }\end{array}$ \\
\hline XIV. & $\begin{array}{l}\text { Did you feel a lack of classroom-like } \\
\text { teacher presence? }\end{array}$ \\
\hline XV. & $\begin{array}{l}\text { Did you agree, everyone, who are part-time } \\
\text { students or are working full time, can take } \\
\text { advantage of web-based learning. }\end{array}$ \\
\hline XVI. & $\begin{array}{l}\text { Did you face a lack of learner motivation } \\
\text { and engagement among students during } \\
\text { online classes? }\end{array}$ \\
\hline XVII. & $\begin{array}{l}\text { Did you face difficulty in finding the } \\
\text { perfect e-learning authoring tool or learning } \\
\text { platform? }\end{array}$ \\
\hline XVIII. & $\begin{array}{l}\text { Have you completed the course at the } \\
\text { scheduled time through online classes? }\end{array}$ \\
\hline
\end{tabular}

\subsection{Data analysis}

Descriptive statistics were carried out to understand the view of participants using advanced numerical tools. The simple percentage distribution was estimated to assess the learning status, mode of learning, and opinion on educational proposals, and problems related to study due to the lockdown were depicted through various pie/bar charts.

\section{RESULTS AND DISCUSSION}

The findings were based on the distributed questionnaire among the participants of all categories including 
students, teachers at post-secondary and higher education standards, skilled e-learning professionals, countrymen of rural and urban areas throughout India (Tables 3-5). The questions compiled for distribution among participants were categorized in three standards based on analysis aptitude (Table 3), multiple choices (Table 4), and fixed action (Table 5) for comparative accounts of conventional pedagogy and e-learning pedagogy adopted after the commencement of the current COVID-19 (Coronavirus Disease- 2019) pandemic due to SARS-CoV-2 (Severe Acute Respiratory Syndrome Coronavirus-2).

Table 3: Questions based on analysis aptitude in the questionnaire

\begin{tabular}{|c|c|c|c|c|c|c|}
\hline \multirow[b]{2}{*}{ S. No. } & \multirow[b]{2}{*}{ Questions } & \multicolumn{5}{|c|}{$\begin{array}{c}\text { The response of } \\
\text { participants against the } \\
\text { given options }\end{array}$} \\
\hline & & 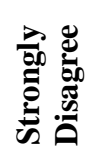 & 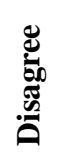 & Z & 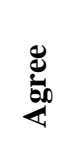 & 常苟 \\
\hline 1. & $\begin{array}{l}\text { Face-to-face } \\
\text { interaction } \\
\text { during class } \\
\text { time in the } \\
\text { traditional } \\
\text { system increase } \\
\text { the confidence } \\
\text { level of a } \\
\text { student: }\end{array}$ & 11 & 10 & 27 & 90 & 72 \\
\hline 2. & $\begin{array}{l}\text { Adopting ICT } \\
\text { and e-learning } \\
\text { allows us to } \\
\text { acquire new } \\
\text { knowledge and } \\
\text { enhance their } \\
\text { skill set: }\end{array}$ & 13 & 18 & 57 & 91 & 31 \\
\hline 3. & $\begin{array}{l}\text { Everyone } \\
\text { knows the } \\
\text { power of digital } \\
\text { media and their } \\
\text { usage in e- } \\
\text { learning; but it } \\
\text { reduces the } \\
\text { practical } \\
\text { exposure in real } \\
\text { life especially } \\
\text { in the field of } \\
\text { medical, civil } \\
\text { engineering, } \\
\text { dental, } \\
\text { architecture, } \\
\text { etc.: }\end{array}$ & 7 & 8 & 36 & 110 & 49 \\
\hline 4. & $\begin{array}{l}\text { Lack of digital } \\
\text { resources } \\
\text { (computer/PC/ } \\
\text { laptop) and } \\
\text { their usage in }\end{array}$ & 12 & 10 & 46 & 88 & 54 \\
\hline
\end{tabular}

\begin{tabular}{|c|c|c|c|c|c|c|}
\hline & $\begin{array}{l}\text { rural/remote } \\
\text { areas of India } \\
\text { while adopting } \\
\text { ICT and e- } \\
\text { learning: }\end{array}$ & & & & & \\
\hline 5. & $\begin{array}{l}\text { The big } \\
\text { challenges } \\
\text { while adopting } \\
\text { ICT-based e- } \\
\text { learning are } \\
\text { data privacy } \\
\text { and security: }\end{array}$ & 5 & 11 & 48 & 103 & 43 \\
\hline 6. & $\begin{array}{l}\text { Learners can't } \\
\text { see the real- } \\
\text { world } \\
\text { implications of } \\
\text { the e-learning } \\
\text { course: }\end{array}$ & 12 & 17 & 74 & 83 & 24 \\
\hline
\end{tabular}

The question focussed on 'May face-to-face interaction during class time in the traditional system increases the confidence level of a student?' received the responses from 210 participants. Among them 72 (34.29\%) strongly agree, $90(42.85 \%)$ agree, $10(4.76 \%)$ disagree, 11 $(5.24 \%)$ strongly disagree and $27(12.86 \%)$ neutral against question (Figure 1).

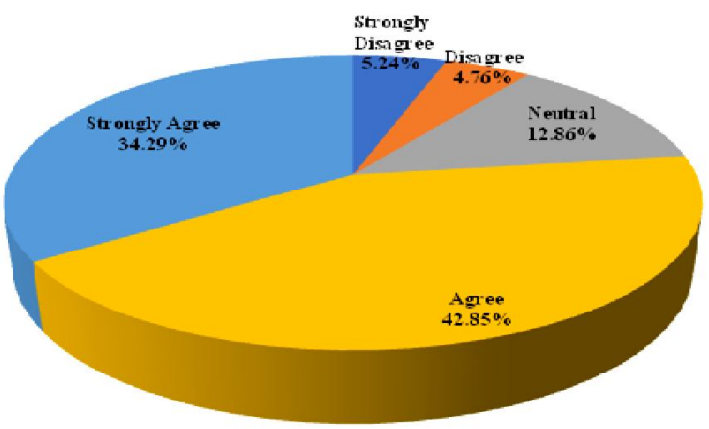

Figure 1: The opinion (\%) about 'does face to face interaction increase the confidence of students?'.

For the question 'Does adopt ICT and e-learning allows to acquire new knowledge and enhance their skill set?' out of 210 participants $31(14.76 \%)$ were strongly agree, $91(43.33 \%)$ agree, $18(8.57 \%)$ disagree, $13(6.19 \%)$ strongly disagree. however $57(27.14 \%)$ neutral (Figure

2).

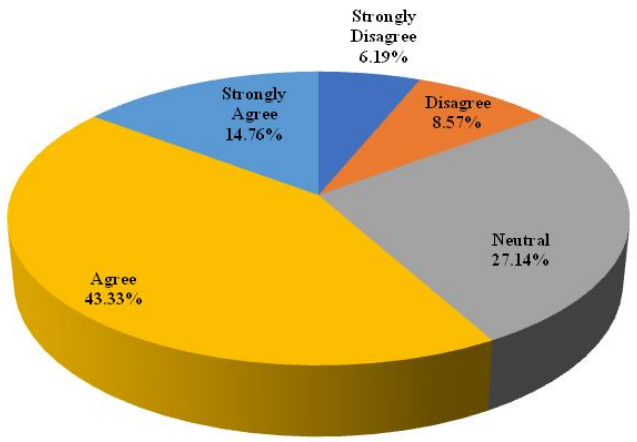

Figure 2: The opinion (\%) about 'does ICT and eLearning allows acquiring new knowledge and enhancing their skill set?' 
The response of 210 participants against the question 'Does e-learning reduces the practical exposure in real life' was recorded. It showed that $49(23.33 \%)$ strongly agreed, $110(52.38 \%)$ agreed, $8(3.81 \%)$ disagreed, 7 $(3.33 \%)$ strongly disagreed and $36(17.14 \%)$ found neutral (Figure 3 ).

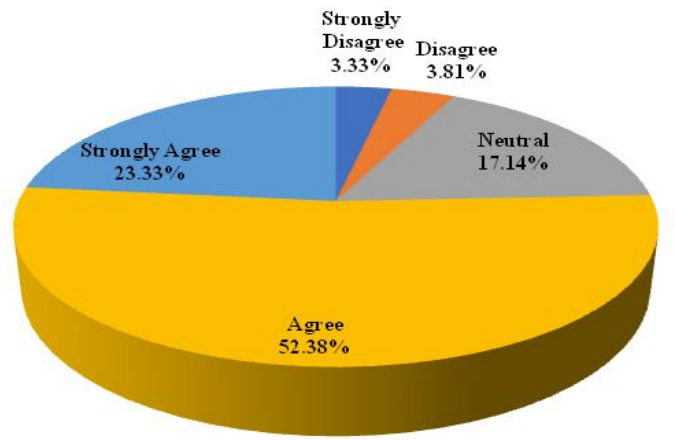

Figure 3: The opinion (\%) about does e-learning leads to less practical exposure in real life.

The next question was related to 'The lack of digital resources (computer/PC/Laptop) and their usage in rural/remote areas in adopting ICT based education system'. Out of 210 participants $54(25.72 \%)$ were strongly agree, $88(41.90 \%)$ agree, $10(4.76 \%)$ disagree, $12(5.72 \%)$ strongly disagree and $46(21.90 \%)$ neutral in response (Figure 4).

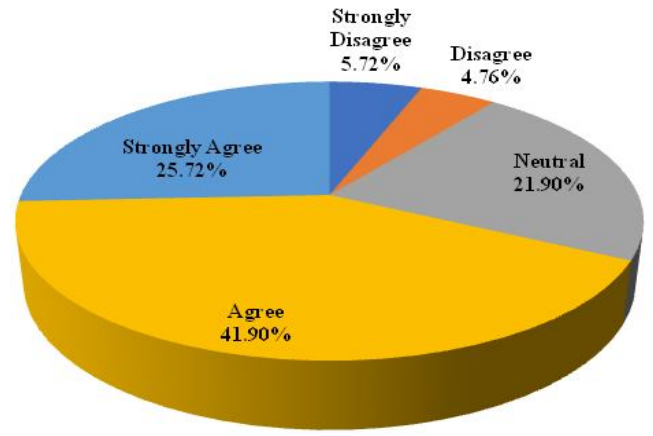

Figure 4: The opinion (\%) about Lack of digital resources (computer/PC/laptop) in Rural/remote areas of India

The responses of 210 participants for the concern about data privacy and security as a big challenge in adopting ICT-based learning were recorded. The 43 (20.48\%) were strongly concerned, 103 (49.04\%) concerned, 11 (5.24\%) not concerned, $5(2.38 \%)$ strongly not concerned and 48 (22.86\%) neutral (Figure 5).

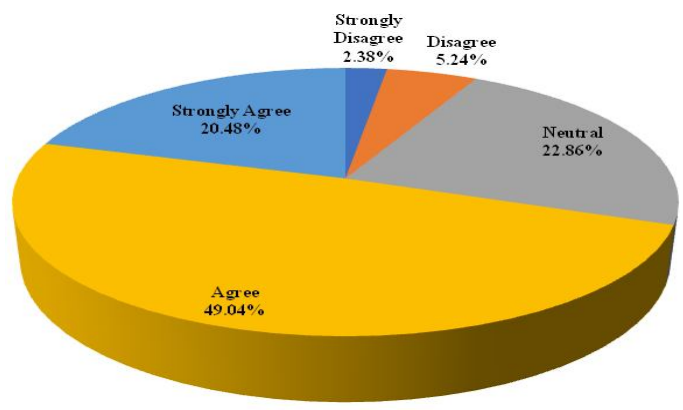

Figure 5: The opinion (\%) about Data Privacy and Security is a big challenge while adopting eLearning
For the question 'Learners can't see the real-world implications of the eLearning course' out of 210 participants $24(11.43 \%$ ) are strongly agree, $83(39.52 \%)$ agrees, $17(8.10 \%)$ disagrees, $12(5.71 \%)$ strongly disagrees and $74(35.24 \%)$ neutral in (Figure 6).

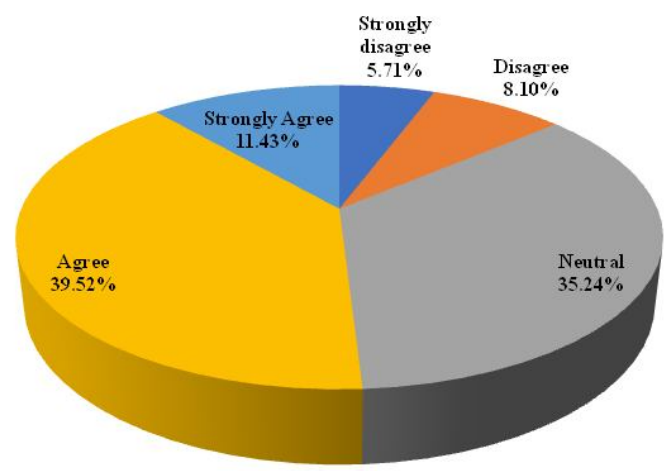

Figure 6: The opinion (\%) about Learners can't see the real-world implications of the eLearning course

Table 4: Multiple choices questions in the questionnaire

\begin{tabular}{|c|c|c|c|c|c|c|c|c|c|c|}
\hline \multirow{3}{*}{\begin{tabular}{|l} 
S. No. \\
1
\end{tabular}} & Questions & \multicolumn{9}{|c|}{$\begin{array}{l}\text { The response of participants } \\
\text { against the given options }\end{array}$} \\
\hline & \multirow[t]{2}{*}{$\begin{array}{l}\text { Which } \\
\text { technical } \\
\text { platform } \\
\text { you are } \\
\text { using for } \\
\text { online } \\
\text { classes? }\end{array}$} & 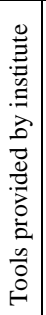 & 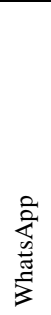 & 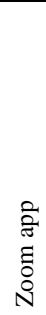 & $\begin{array}{l}\stackrel{\Xi}{0} \\
\sum_{0}^{\infty} \\
\frac{0}{00} \\
8 \\
0\end{array}$ & 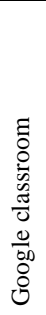 & 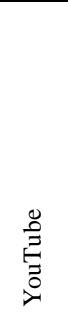 & 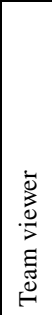 & 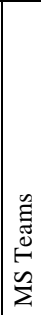 & 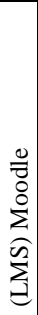 \\
\hline & & 35 & 69 & 133 & 70 & 31 & 58 & 14 & 46 & 10 \\
\hline \multirow[t]{2}{*}{2} & \multirow[t]{2}{*}{$\begin{array}{l}\text { How do you } \\
\text { feel during } \\
\text { online } \\
\text { teaching/lea } \\
\text { rning as } \\
\text { compared } \\
\text { to class } \\
\text { room } \\
\text { teaching/lea } \\
\text { rning? }\end{array}$} & 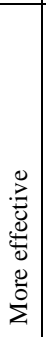 & 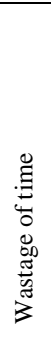 & $\stackrel{\Xi}{\mathscr{D}}$ & 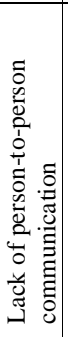 & 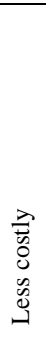 & & & & \\
\hline & & 36 & 41 & 12 & 109 & 12 & & & & \\
\hline \multirow[t]{2}{*}{3} & \multirow[t]{2}{*}{$\begin{array}{l}\text { Which } \\
\text { problems } \\
\text { have you } \\
\text { faced } \\
\text { during } \\
\text { online } \\
\text { classes? }\end{array}$} & 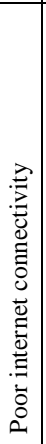 & 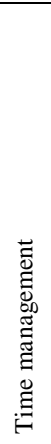 & 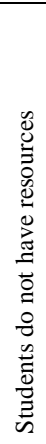 & 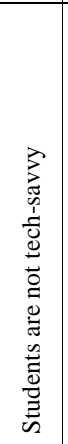 & 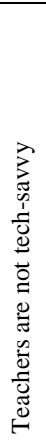 & 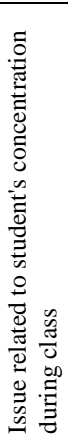 & 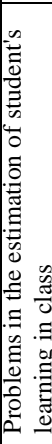 & & \\
\hline & & 149 & 48 & 73 & 31 & 26 & 100 & 66 & & \\
\hline 4 & $\begin{array}{l}\text { What is the } \\
\text { reaction of } \\
\text { your family } \\
\text { about online }\end{array}$ & $\begin{array}{l}\overrightarrow{0} \\
8 \\
0 \\
2 \\
\overrightarrow{0} \\
>\end{array}$ & $\begin{array}{l}\ddot{8} \\
\dot{0} \\
\dot{0}\end{array}$ & 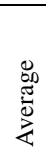 & ¿ั & $\begin{array}{l}2 \\
\vdots \\
2 \\
0 \\
0\end{array}$ & & & & \\
\hline
\end{tabular}




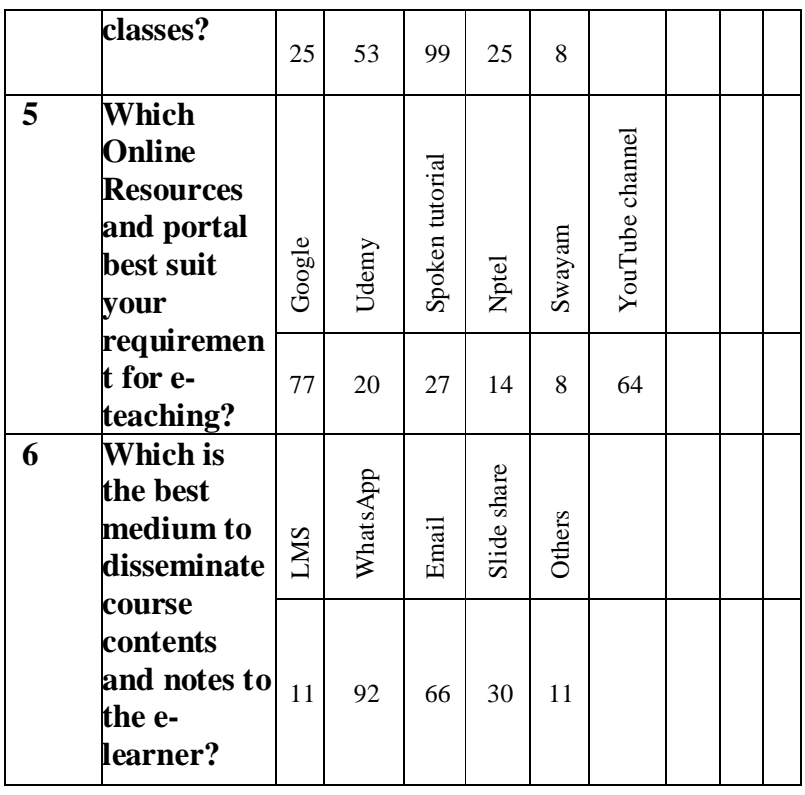

For the question 'Which technical platform you are using for online classes?' participants can choose multiple answers against the question.35, 69, 133, 70, 31, 58, 14, 46 , and 10 votes were recorded respectively for an application provided by institute/college/University, WhatsApp, Zoom app, Google classroom, YouTube, Team viewer, Microsoft teams, and Learning Management System(LMS)/Moodle in (Figure 7).

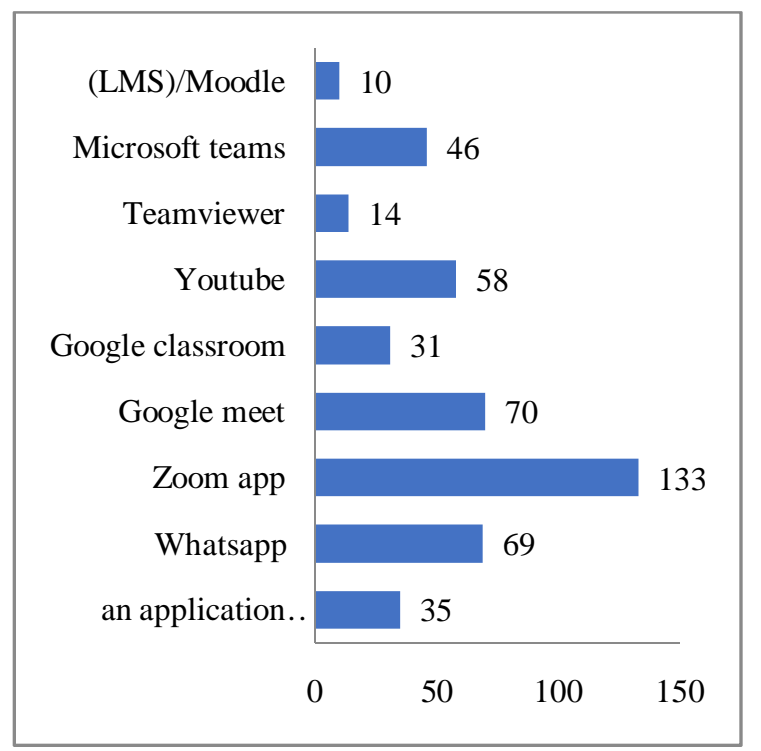

Figure 7: Which technical platform you are using for online classes?

For the question 'How do you feel during online teaching/learning as compare to classroom teaching/learning?' out of 210 participants $36(17.14 \%)$ choose the more effective, 41(19.52\%) choose the wasting of time, 12(5.72\%) choose tried, 109(51.90\%) choose lack of person to person communication and $12(5.72 \%)$ choose the less costly option (Figure 8 ).

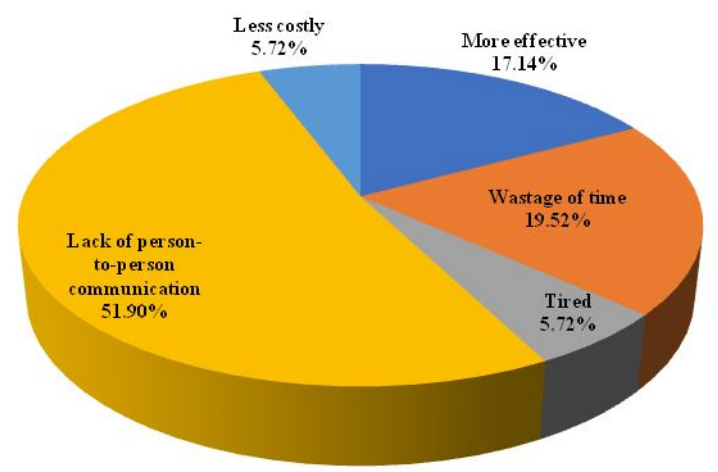

Figure 8: The opinion (\%) about feeling during online teaching/learning as compared to classroom teaching/learning

For the question 'Which problems have you faced during online classes?', participants can choose multiple issues/problems out of given options.149, 48, 73, 31, 26, 100 and 66 vote were recorded respectively poor internet connectivity, time management, Students do not have resources, Students are not tech-savvy, Teachers are not tech-savvy, Issue related to student's concentration during class, and Problem in the estimation of student's learning in class (Figure 9).

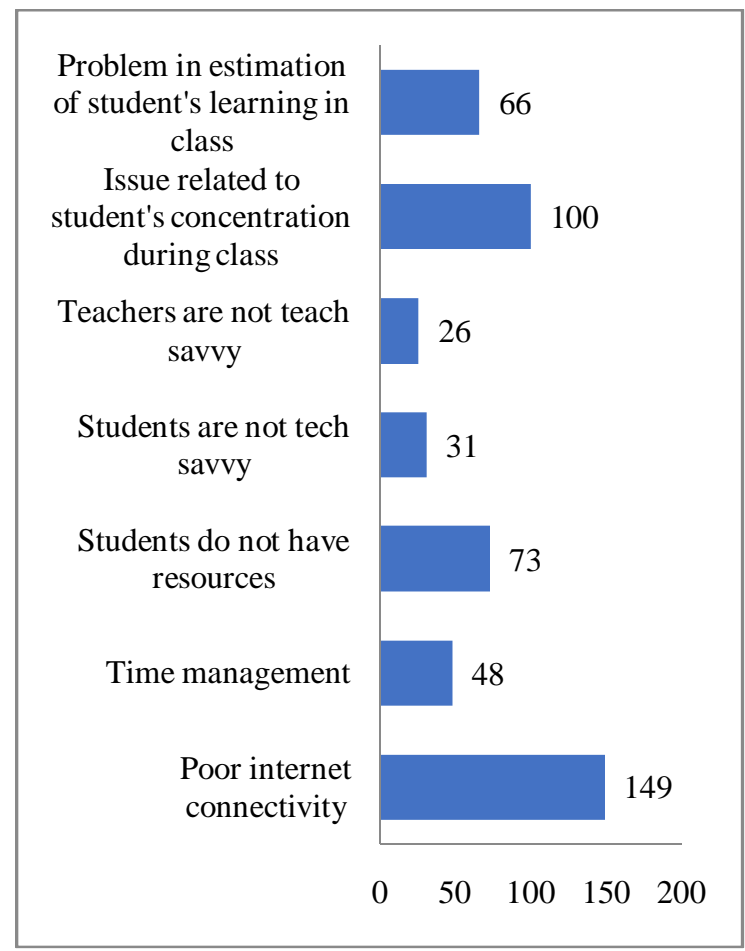

Figure 9: The opinion about problems have you faced during online classes.

For the question 'What is the reaction of your family about online classes?' out of 210 participants $25(11.90 \%)$ choose very good, 53(25.24\%) choose good, 99(47.14\%) choose average, $25(11.90 \%)$, choose poor, $8(3.82 \%)$ choose very poor (Figure 10). 


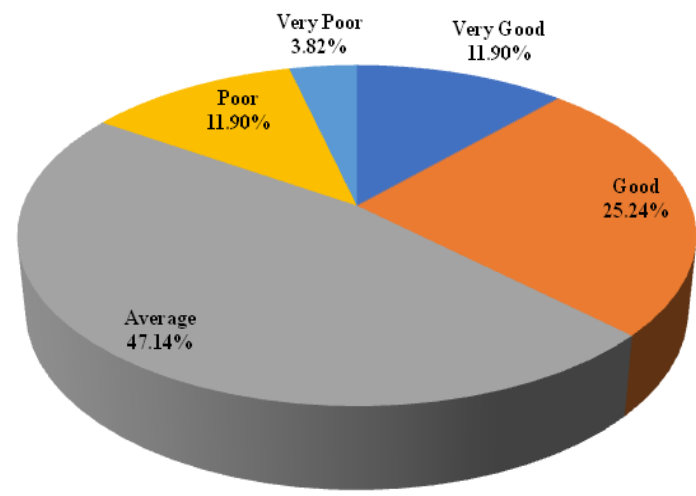

Figure 10: The opinion (\%) about the reaction of your family about online classes.

When it was asked to participants which online resource and portal suits to fulfill their requirement for e-learning and teaching, 77(36.67\%) chose Google, 20(9.52\%) choose Udemy, 27(12.86\%) choose spoken tutorial, 14(6.67\%) choose NPTEL, 8(3.81\%) choose Swayam Portal, 64(30.48\%) choose YouTube (Figure 11).

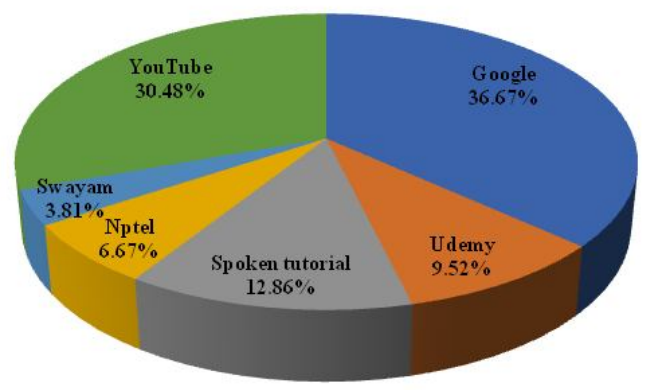

Figure 11: The opinion (\%) about online resources and portal that suits requirement for e-teaching

Out of 210 participants $11(5.24 \%)$ choose LMS, 92(43.81\%) choose WhatsApp, 66(31.43\%) choose Email, 30(14.29\%) choose Slide share and 11(5.24\%) choose the others, for the best medium to disseminate course contents and notes to the e-learner (Figure 12).

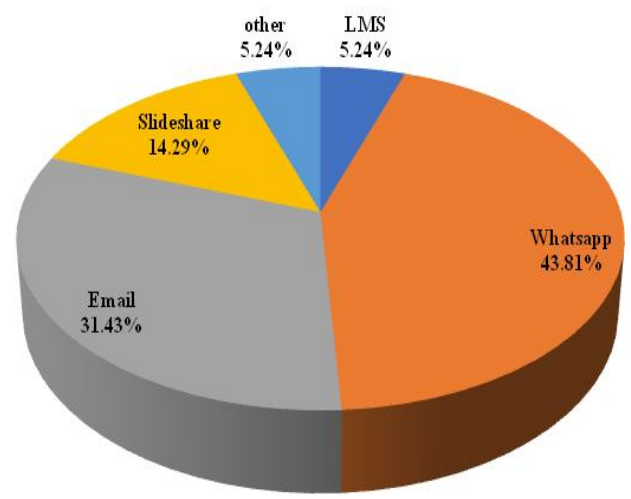

Figure 12: The opinion (\%) about the best medium to disseminate course contents and notes to the e-learner.
Table 5: Fixed action based questions in the questionnaire

\begin{tabular}{|c|c|c|c|c|}
\hline \multirow{2}{*}{ S. No. } & \multirow{2}{*}{ Questions } & \multicolumn{3}{|c|}{ Response } \\
\hline & & Yes & No & May be \\
\hline 1 & $\begin{array}{l}\text { Did you feel a lack of } \\
\text { classroom-like teacher } \\
\text { presence? }\end{array}$ & 121 & 44 & 45 \\
\hline 2 & $\begin{array}{l}\text { Did you agree, everyone, } \\
\text { who are part-time students } \\
\text { or are working full time, } \\
\text { can take advantage of web- } \\
\text { based learning }\end{array}$ & 129 & 23 & 58 \\
\hline 3 & $\begin{array}{l}\text { Did you face a lack of } \\
\text { learner motivation and } \\
\text { engagement among } \\
\text { students during online } \\
\text { classes? }\end{array}$ & 120 & 31 & 59 \\
\hline 4 & $\begin{array}{l}\text { Did you face difficulty in } \\
\text { finding the perfect e- } \\
\text { learning authoring tool or } \\
\text { learning platform? }\end{array}$ & 105 & 53 & 52 \\
\hline 5 & $\begin{array}{l}\text { Have you completed the } \\
\text { course at the scheduled } \\
\text { time through online } \\
\text { classes? }\end{array}$ & 82 & 54 & 74 \\
\hline 6 & $\begin{array}{l}\text { Have you used ICT for the } \\
\text { e-Learning platform before } \\
\text { the COVID-19 pandemic? }\end{array}$ & 102 & 108 & - \\
\hline
\end{tabular}

Out of 210 participants, 102(48.57\%) participants used the ICT For e-learning platform before the COVID-19 pandemic where $108(51.43 \%)$ participants never used ICT for e-learning before the pandemic (Table 5). $121(57.62 \%)$ participants feel a lack of classroom-like teacher presence and 44(20.95\%) participants do not feel a lack of classroom-like teacher presence during online classes and 45(21.43\%) participants respond neither positive nor negative (Table 5). Out of 210, 129(61.43\%) participants agree part-time and full-time students can take the advantage of web-based learning, 23(10.95\%) participants do not agree with the same, and 58(27.62\%) participants respond neither positive nor negative (Table 5). $120(57.14 \%)$ yes, $31(14.76 \%)$ no, 59(28.10\%) may be Did you face a lack of learner motivation and engagement among students during online classes? (Table 5). $105(50.00 \%)$ yes, $53(25.24 \%)$ no, 52(24.76\%) maybe Did you face difficulty in finding the perfect e-learning authoring tool or learning platform? (Table 5). $82(39.05 \%)$ yes, $54(25.71 \%)$ no, $74(35.24 \%)$ Have you completed the course in scheduled time through online classes? (Table 5). 


\section{CONCLUSIONS}

India is the second-largest populated country in the world. A large group of people is involved in teaching-learning activities in India. The education sector is exploring information communication technology (ICT) for making teaching and learning attractive and useful. During the COVID-19 pandemic, teaching-learning activities shifted to online education practices from the conventional way of education. The study through the online survey reflected as people felt that the face to face interaction can build the confidence of learner, however ICT based education could help to explore the new edges of education. Most of the people said that online education has less exposure to real-time implementation for practical knowledge. Since India is a developing country, information technology infrastructure is not as good as developed countries. More especially in rural and remote areas people facing scarcity of resources that is the hurdle for adopting online education in the current scenario. During the investigation, the zoom app was widely used for online education, and the users were concerned about data security and privacy. Poor internet connectivity, student's learning estimation, and lack of concentration during online classes are the major problem faced by the teachers and students. The internet played a crucial role in education, Google and YouTube were the highly applicable platform for educational activities during Govt. enforced lockdown to curve the effect of the COVID-19 pandemic. E-mail and WhatsApp were the best medium to disseminate course contents and class notes to the elearner. There were $51.43 \%$ of participants never used ICT based education before the COVID-19 pandemic that revealed the lack of motivation, training, and engagement of students and teachers. ICT based education could be a cutting edge technology for education but during the survey people felt constrains of the perfect tools for the teaching-learning activities. Online teaching-learning can't replace the conventional methodology of education but it can build the conventional education system more effective. Thus it is the time to adopt online education after proper training of both teachers and students.

\section{REFERENCES}

1. Abidah, A., Hidaayatullaah, H. N., Simamora, R. M., Fehabutar, D., \& Mutakinati, L.(2020). The impact of Covid-19 to Indonesian education and its relation to the philosophy of "MerdekaBelajar", SiPoSE: Studies in Philosophy of Science and Education,1(1), 38-49.

2. Al-Okaily, M., Alqudah, H., Matar, A., Lutfi, A., \& Taamneh, A. Dataset on the Acceptance of elearning System among Universities Students' under the COVID-19 Pandemic Conditions, Data in brief, 32, 106176, 2020.

3. Al-Okaily, M., M Alqudah, H., Matar, A., Lutfi, A., \& Taamneh, A. Impact of Covid-19 Pandemic on Acceptance Of E-Learning System In Jordan: A Case of Transforming the Traditional Education Systems, Humanities \& Social Sciences Reviews, 8(4), 840-851, 2020.
4. Bylieva, D., Bekirogullari, Z., Lobatyuk, V., \& Nam, T. Analysis of the consequences of the transition to online learning on the example of mooc philosophy during the covid-19 pandemic, Humanities \& Social Sciences Reviews, 8(4), 10831093, 2020.

5. Dhawan, S. Online Learning: A Panacea in the Time of COVID-19 Crisis, Journal of Educational Technology Systems, 49(1), 5-22, 2020.

6. Gon S., Rawekar A. Effectivity of E-Learning through Whatsapp as a Teaching Learning Tool, MVP Journal of Medical Sciences, Vol 4(1), 19-25, 2017.

7. Gonzalez, T., de la Rubia, M. A., Hincz, K. P., Comas-Lopez, M., Subirats, L., Fort, S., \& Sacha, G. M. Influence of COVID-19 confinement in students performance in higher education, arXiv preprint arXiv:2004.09545, 2020.

8. Goyal, S. Impact of Coronavirus on Education in India, https://www.jagranjosh.com/articles/d mrcresult-2020-released-delhimetrorailcom-che ck-cutoff-marks-1587122899-1?itm (Accessed on 27 July, 2020)

9. India Today. Effect of Covid-19 on campus: Major steps being taken by Colleges to keep education going. https://www.indiatoday.in /education-today/featurephilia/story/effect-of-covid19-on-campus-steps-taken-by-colleges 16681562020-04-17. (Accessed on 17 April 2020)

10. Kapasia. N., Paul P., Roy A.,Saha J.,Zaveri A., Mallick R., Barman B., Das P., Chouhan P. Impact of lockdown on learning status of undergraduate and postgraduate students during COVID-19 pandemic in West Bengal, India, Children and Youth Services Review, 116, 105194, 2020.

11. Kumar, D. N. S. Impact of Covid-19 on Higher Education. Higher Education Digest. https://www.highereducationdigest.com/impact-ofcovid-19-on-highereducation/. (Accessed on 12 May 2020)

12. Ministry of Health and Family Welfare. https://www.mohfw.gov.in/ COVID COVID-19 INDIA. (Accessed on 6 September 2020)

13. Pelmin, M. (2020). Readings on Coronavirus Disease (COVID-19) and the Higher Education Institution (HEIs) Emergency Preparedness in the Philippines. Available at SSRN 3573896. https://ssrn.com/a bstract=3573896

14. Perraton, H. A theory for distance education. Prospects, 11, 13-24, 1981.

15. S Haider, A., \& Al-Salman, S. Covid-19's impact on the higher education system in jordan: advantages, challenges, and suggestions, Humanities \& Social Sciences Reviews, 8(4), 14181428, 2020. 
16. Singh, G., Bhatnagar, V., Gupta, R., \& Kumar, G. Exploration of e-learning vs traditional learning in india, Humanities \& Social Sciences Reviews, 8(2), 69-76, 2020.

17. Sood S, Aggarwal V, Aggarwal D, Upadhyay SK, Sak K, Tuli HS, Kumar M, Kumar J, Talwar S. Covid-19 pandemic: From molecular biology, pathogenesis, detection and treatment to global societal impact, Curr Pharma Rep., 2020.

18. Strielkowski, W. COVID-19 pandemic and the digital revolution in academia andhigher education. Preprints 2020, 2020040290.

19. UNESCO(2020).Education: From disruption to recovery. https://en.unesco.org/covid19/e ducationresponse/.

20. Upadhyay SK, Singh R, Babita, Kumar G, Singh G. (2020). The outbreak and challenges of novel coronavirus (COVID-19): The global pandemic emergency of early 2K20 and Indian scenario. Int J Biol Pharma All Sci. 9(5), 1173-99. http://doi.org/10.31032/IJBPAS/2020/9.5.5126

21. Upadhyay SK, Singh R, Singh M, Kumar V, Yadav M, Aggarwal D, Sehrawat N. (2020). COVID-19 in republic of India: A report on situation and precautionary strategies to global pandemic. Bull Environ Pharmacol Life Sci., 9(6), 39-48.

22. WHO Timeline - COVID-19, April 2020, https://www.who.int/news-room/detail/27-042020-who-timeline-covid-19. World Health Organisation.

23. Zaharah, Z., Kirilova, G., \& Windarti, A. Impact of Corona Virus Outbreak Towards Teaching and Learning Activities in Indonesia, SALAM: Jurnal Sosial dan Budaya Syar-i, 7(3), 269-282, 2020. 